\title{
THE GEOGRAPHICAL IDENTITY OF PORTUGAL, WITH SPECIAL REFERENCE TO THE WORKS OF STANISLAWSKI
}

DAVID HOOSON ${ }^{1}$

\begin{abstract}
These post-Soviet years have brought a return of geography, along with history, after the long period of ideologically controlled uniformity. There is, in particular, a felt need for resurrection of the kind of regional and historical geography which was practiced in the tradition of the French schools of Vidal de La Blache and the Annales on the one hand, and the Berkeley school of historical-cultural geography, personified by Sauer, on the other. The paper examines the contribution of Stanislawski, an essential regional, cultural-historical Berkeley geographer who had written three books and several articles on Portugal.
\end{abstract}

Key-words: Regional geography, identity of Portugal, Stanislawski, Orlando Ribeiro.

Résumé: L'IdENTITE GEOGRAPHIQUE DU PORTUGAL, AVEC REFERENCE SPECIALE AUX TRAVAUX DE STANISLAWSKI - Les années postsoviétiques ont apporté un retour à la géographie, ainsi qu'à l'histoire, après une longue période d'uniformité à forte contrainte idéologique. On remarque, en particulier, un besoin de récupération d'un genre de géographie régionale et historique qui fut pratiquée selon les traditions de l'école française de Vidal de La Blache et des Annales, d'une part, et de l'école de Berkeley de géographie historico-culturelle representée par Sauer, d'autre part. Le texte analyse la contribution de Stanislawski, un géographe de Berkeley, essentiellement régional et historico-culturel, qui écrivit trois livres et plusieurs articles sur le Portugal.

Mots-clés: Géographie régionale, identité portugaise, Stanislawski, Orlando Ribeiro.

Resumo: A IDENTIDADE GEOGRÁFICA DE PORTUGAL, COM ESPECIAL REFERÊNCIA AO TRABALHO DE STANISLAWSKI - Os anos pós-soviéticos levaram a uma reaparição da geografia e da história, depois de um longo período de forte controlo ideológico. Nota-se, em particular a necessidade de recuperação de uma geografia regional e histórica na tradição, por um lado, da escola francesa de Vidal de La Blache e dos Annales e, por outro lado, da escola de geografia histórico-cultural de Berkeley, representada por Sauer. O texto analisa o contributo de Stanilawski, um geógrafo de

1 University of California, Berkeley. Deparment of Geography, $401 \mathrm{Mc}$ Cone Hall 4740, Berkeley, California 94720, USA. Fax: 510 642-3370. 
Berkeley essencialmente regional e histórico-cultural, que escreveu três livros e vários artigos sobre Portugal.

Palavras-chave: Geografia regional, identidade portuguesa, Stanislawski, Orlando Ribeiro.

Growing up in Wales, I heard Portugal frequently described as "Britain's oldest ally", and was intrigued by this apparent kinship might mean. Both had far-flung, longestablished empires and a thoroughly Atlantic outlook, with fishing and maritime traditions. Later I learned about the Anglo-Portuguese identity of Prince Henry the Navigator and visited his geographical "think-tank" at Sagres looking out on the Atlantic ocean. During my time at Oxford I was impressed by the peculiar importance of the Port wine connection, and later marvelled at the fusion of man and nature in the Minho region and the row of Port ware houses along the Douro river. But as a geographer I never had a chance to do research on Portugal, being consigned by fate to specialize on a country, now defunct, which was deemed to be of much greater importance - the Soviet Union! My curiosity about Portugal persisted, however, and was rekindled by my friendship with and old colleague at the University of California at Berkeley who had written three books and several articles on Portugal. Before I describe him and his work - essentially regional, cultural-historical studies, I wish to set out the context of the history of our subject - geography - in recent decades.

\section{GEOGRAPHY AND REGIONAL STUDIES}

Throughout its long history, the geographical profession, at least until about 1960, assumed that the "Crowning chapter" of the profession integrated the many physical and human systematic studies which constituted their "building blocks". Following the institutionalization of the subject in European universities in the late nineteenth century, the leaders, such as Vidal de La Blache, Richthofen and Mackinder all maintained this position, and a major survey of American geography in 1954 was able to assert that regional geography was still in a prominent position (JAMES and JONES, 1954). However, in the wake of the cybernetic innovations and the consequent rise of "Big Science" in the context of the Cold War and rearmament, a so-called New Geography was born, with an emphasis on statistical techniques and theoretical model-building. The effect of this innovations was to focus attention on various topical rather than regional themes, particularly in economic geography, on contemporary situations rather historical antecedents and, because of the availability of data, on advanced industrial countries rather than the under-developed "Third World" where most of the world's people lived. Regional geography, with its myriad, often intangible variables and its typically historical and cultural approach was overshadowed and often denigrated. It became quite fashionable for young geographers to disclaim any regional specialism for themselves and many geography departments in the United States restricted, or even 
abolished, regional courses. Only in the 1990s following the collapse of the Soviet Union and the global ideological bi-polar mind-set has there been a revival of interest in regional identities and specific regional-historical studies.

\section{STANISLAWSKI AND PORTUGAL}

Dan Stanislawski, who died in 1997 at the age of 94, was a fine exemplar of that earlier tradition in historical, cultural and regional geography, and he happened to fall in love with Portugal where he spent 1952-1953 on a Guggenheim Fellowship. This encounter resulted in three books and several articles on the country, so that he stands out as the prime interpreter of Portuguese geography in the English-speaking world. Other European geographers who had written about Portugal included notably Hermann Lautensach and Pierre Birot, and indeed the regional tradition was alive and well in Portugal itself under the inspiring leadership of Orlando Ribeiro of Lisbon, whom Stanislawski much admired. When I went to Lisbon for an International Geographical Congress in 1998, I hoped to meet Ribeiro and pass on Stanislawski's greetings, only to discover that he had died in the previous year. However I was able to learn about the spirit of historical and regional geography in Portugal from native scholars there, notably Dr. Maria Fernanda Alegria, from which it appeared that this kind of scholarly work had indeed been flourishing and wide-ranging but, as in other parts of the world, had become relatively "endangered" in recent years in comparison with other more applied, contemporary work (RIBEIRO et al.,1995).

To return to Stanislawski, he was late beginner in geographical research, receiving his Ph.D. under Carl Sauer in Berkeley when he was already 41. His early work was on Mexico and Central America and included historical work on the pre-Columbian Tarascan state and early Spanish town planning. However his involvement not only with Portugal but also with Italy and Greece increasingly dominated his scholarly attention. His first book on Portugal, The Individuality of Portugal, which he sub-titled "a study in Historical-Political Geography" (STANISLAWSKI, 1959) is a profound study of the historical stages and factors in the creation of a national identity. Later he published a book on the Algarve entitled Portugal's other Kingdom (STANISLAWSKI, 1963), based on detailed field work and again focussing on the geographical identities of the subregions, with deep historical and physical analysis and excellent illustrations.

Stanislawski was very knowledgeable about wine, and this was so much part of his love of Portugal that he published a third book called Landscapes of Bacchus: The wine in Portugal (STANISLAWSKI, 1970). This again is beautifully illustrated and treated in detailed regional-historical fashion - the best tribute and guide to the geography of Portuguese wines written in English. After his years in Portugal he went on to study the wine in Italy and Greece, going back to the classical times. He wrote many articles on these themes, the most remarkable and exciting being "Dionysus Westward: Early Religion and the Economic Geography of Wine" (STANISLAWSKI, 1975). It is a paean of praise for the blessed wine and for the age old healthful and uplifting qualities of wine in the Mediterranean world, written at a time when 
Americans were still somewhat uncivilized in their attitude to it (except in Northern California, where there are many Portuguese and Italian immigrants!).

I hope these brief references have given, for the readers of this journal, some flavor of this great scholar of Portugal, the Mediterranean and Latin America, who had developed an specially abiding love for Portugal. Now that English has, for better or worse, replaced French and German as a world language, it seems fortunate that Stanislawski's books on Portugal are available, so that the increasinglymonoglot English and American public can have access to such detailed and vividly written books about a country which has largely been overlooked (for instance, by comparison with Spain) by foreign geographers. By the way, the citation, when he was awarded Medal of Honor in 1963 by the Association of American Geographers, read "for his perceptive studies on the Portuguese people".

When his books appeared, three or four decades ago Portugal was, of course, a significantly different country than it is today. It was still very much a rural, peasant land and society, without a democratic government and with its vast overseas empire still mostly intact, and rather separated from post-war Europe. Now, its empire gone, with a democratic government and in the European Union, with rapid urbanization and industrialization it is in many ways a different country, especially Lisbon and environs.

However the country that Ribeiro and Stanislawski wrote about is still there in a fundamental sense - Atlantic country par excellence, with a long history and a strong individuality which marks it off clearly from Spain and from the rest of Europe and is the product of a long association of a close-knit culture with its particular regions and environments. Though all the recent changes brought by the Information Age and Globalization, the individual identity of Portugal survives and perhaps has even become more rather than less important than before (HoOsON, 1994).

For it is a remarkable fact that since the end of the Cold War and the collapse of the Soviet empire, there has been an upsurge of feelings of national and regional identity which have become more and more insistent, in Europe and across the world. A "Europe of Regions" is crystallizing at the same time as the attempts at European integration and those places with a definite and homogeneous identity have a better chance to prosper than those which lack these qualities.

These post-Soviet years have brought a return of Geography, along with History, after the long period of ideologically controlled uniformity. There is, in particular, a felt need for resurrection of the kind of regional and historical geography which was practiced by scholars like Ribeiro and Stanislawski, in the traditions in which they grew up - the French schools of Vidal de La Blache and the Annales on the one hand, and the Berkeley school of historical-cultural geography, personified by Sauer, on the other.

After the long period when academic geography somehow slipped from its roots in the human regional tradition, it is high time to find them again and thus to satisfy the age-old human need to really understand the nature and origins of the world's disctinctive regions and peoples. In this quest, Portugal will always be a rewarding and wonderful place to explore geographical realities and the interplay between tradition and change. National identites and long-term geographical assets and constraints are 
being increasingly recognized by historians, economists and politicians as crucial to the prediction of success of regions and peoples.

\section{BIBLIOGRAPHY}

Hooson, D. (ed.) (1994) - Geography and National Identity. Blackwells, Oxford.

JAMES, P.E.; C.F. JONES (ed.) (1954) - American Geography. Inventory and Prospect. Syracuse NY.

Ribeiro, O.; S. DAVEAU; J. C. GARCiA; M. F. Alegria (1995) - Les recherches de géographie historique au Portugal. In R. PITTE (ed.): Géographie Historique et Culturelle de l'Europe: Hommage au Professeur Xavier de Planhol. P.U.P., Paris: 330-351.

StanislawsKi, D. (1959) - The Individuality of Portugal: A Study in Historical-Political Geography. University of Texas Press, Austin.

StanislawSKI. D. (1963) - Portugal's Other Kingdom: The Algarve. University of Texas Press, Austin.

STANISLAWSKI, D. (1970) - Landscapes of Bacchus: the Wine in Portugal. University of Texas Press, Austin.

STANISLAWSKI, D. (1975) - Dyonysus Westward: Early Religion and the Economic Geography of Wine. Geographical Review, 65 (4): 427-44. 